\title{
Pharmacognostic and Antimicrobial Studies of Garcinia latissima Miq. Leaves (Clusiaceae)
}

\author{
Neneng Siti Silfi Ambarwati ${ }^{{ }^{*}}$, Islamudin Ahmad ${ }^{2}$, Berna Elya ${ }^{3 *}$, Amarila Malik ${ }^{4}$, Muhamad Hanafi ${ }^{5}$
}

\section{Neneng Siti Silfi Ambarwati ${ }^{1 *}$, Islamudin Ahmad $^{2}$, Berna Elya ${ }^{3 *}$, Amarila Malik ${ }^{4}$, Muhamad Hanafi ${ }^{5}$}

'Department of Health and Beauty, Faculty of Engineering, Jakarta State University, Jl. Rawamangun Muka, East Jakarta, INDONESIA.

${ }^{2}$ Department of Pharmaceutical Sciences, Faculty of Pharmacy, Universitas Mulawarman, Samarinda, East Kalimantan, INDONESIA. ${ }^{3}$ Laboratory of PharmacognosyPhytochemistry, Faculty of Pharmacy, Universitas Indonesia, Kampus UI Depok, Depok 16424, INDONESIA. ${ }^{4}$ Laboratory of MicrobiologyBiotechnology, Faculty of Pharmacy, Universitas Indonesia, Kampus UI Depok, Depok 16424, INDONESIA. ${ }^{5}$ Research Center for Chemistry, Indonesian Institute of Sciences-LIPI, PUSPIPTEK, Serpong 15314, INDONESIA.

\section{Correspondence}

Neneng Siti Silfi Ambarwati and Berna Elya, Gedung H Lantai 3 UNJ JI. Rawamangun Muka Jakarta Timur, INDONESIA.

Phone numbers : +6281399439923 and +6281314161497

E-mail: neneng_ambarwati@yahoo.co.id \& berna.elya@gmail.com

\section{History}

- Submission Date: 23-02-2017;

- Review completed: 04-03-2017;

- Accepted Date: 03-05-2017

DOI : 10.5530/pj.2017.4.80

Article Available online

http://www.phcogj.com/v9/i4

\section{Copyright}

(C) 2017 Phcog.Net. This is an openaccess article distributed under the terms of the Creative Commons Attribution 4.0 International license.

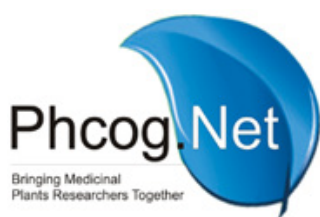

\begin{abstract}
Introduction: Garcinia latissima Miq known as Dolo magota (Maluku), is a medicinal plant belonging to the family Clusiaceae. The purpose of the research was to explore the phytoconstituents present, pharmacognostic details, and their antimicrobial efficacy. Methods: The preliminary phytochemical components were qualitatively examined using the standard method systems. The antimicrobial screening was carried out using the good diffusion method and the minimum inhibitory concentration (MIC) using dilution method. Results: The phytochemical screening of different extract of G. latissima Miq leaves revealed the presence of tannins, saponins, and alkaloids and the results were tabulated. The ethyl acetate and methanolic extracts from its leaves showed antimicrobial activity especially for Bacillus subtilis, a positive bacteria; the hexane extract did not show any activity against the selected microba. Conclusion: The results of the phytochemical and bio-efficacy study revealed most valuable information and also support the continued sustainable use of this leaves in the traditional system of medicine.

Key words: Garcinia Latissima, Antimicrobial, Phytoconstituent, Pharmacognostical.
\end{abstract}

\section{INTRODUCTION}

Garcinia latissima is one species of Guttiferae familia and also called Clusiaceae. ${ }^{1,2}$ Their fruit like G. mangostana or mangosteen, G. parvifolia or kandis, G. dulcis or mundu, and G. xanthoxymus are edible, sweet, with no acid. ${ }^{3}$ In addition to widely spread in Indonesia, this plant also spread in sub-tropical regions such as Japan, Korea, and China, tropical Asian, African, and Polynesian country ${ }^{2-4}$. This family is known to contain the yellow sap, which is a source of camboge paint and varnish, like G. mangostana, G. dulcis (Thailand, India, Sri Lanka), G. hanburyi (Thailand), G. morrella (India)., ${ }^{5,6}$ The contains of yellow sap are generally contains resins, oils, and sometimes have black or red glands, that contains hypericin or pseudohiperisin.?

Previous research in Papua New Guinea showed that ethanol extract of it dried stem bark has a zone of inhibition against the bacteria Bacillus subtilis and Staphylococcus aureu. ${ }^{8}$ It also has been found that G. latissima Miq. stem bark from the center of the province of Papua New Guinea has four new pyranoxanthones, which are latisxanthone-A, latisxanthone- $\mathrm{B}$, latisxanthone-C, and latisxanthone-D. ${ }^{9}$ The biological activity of latisxanthone-C showed that it significantly inhibit the activity of viral antigen, which is the causes of tumors..$^{10}$ The data of secondary metabolite of it leaves is limited.

This plant, which is called Dolo magota by the local (Maluku), is found in Seram Maluku and Papua but has been cultivated in the Garden. ${ }^{11}$ By the local community in Papua, it has been used as itchy medicine. This research used the one that came from Bogor. $^{?}$

This research has a purpose which is to explore the phytoconstituents present, pharmacognostical details, the biological activities of G. latissima Miq. leaves as antimicrobial, making it useful in subsequent drug development.

\section{MATERIALS AND METHODS}

Plant material: G. latissima Miq. leaves were collected and identified from Plant Conservation, Bogor Botanical Gardens, Indonesian Institute of Sciences. After that it was washed, cut into small pieces, and dried in the oven. Dried material is stored in a sealed container in a cool, dry place. ${ }^{12}$

\section{Macroscopic characteristics}

For morphological observations, $15-30 \mathrm{~cm}$ long fresh leaves were used. The magnifying lens was used to observed the macromorphological features of the leaf. ${ }^{13}$

\section{Microscopic characteristics}

Fresh and dry leaf are examined with microscopy was taken using Nikon Coolpix 4500 camera (4.0 megapixel).

\section{Extraction processes}

This study uses multilevel maceration extraction methods. ${ }^{12}$ Powdered leaves material was extracted by repeated maceration at room temperature using 
various solvents: hexane, ethyl acetate, and methanol in a row. After extraction, the filtrate was evaporated using rotary evaporator. ${ }^{14}$ The residue (crude extract) was collected and stored at $4^{\circ} \mathrm{C}$ before used. ${ }^{15}$

\section{Phytochemical analysis}

The qualitative phytochemical tests of hexane extract, ethyl acetate extract, methanol extract were carried out to identify different phytoconstituents. ${ }^{13}$

\section{Antimicrobial activity}

This research has conducted two kinds of examination which are, inhibition zone assay, minimum inhibitory concentration (MIC), and the minimum bactericidal concentration (MBC) assay. The inhibition zone assay using the well diffusion method. Four bacterial strains that were used are, Staphylococcus aureus ATCC 25923, Escherichia coli ATCC 25922, Pseudomonas aeroginosa ATCC 27853, and Bacillus subtilis ATCC 6633, and the two fungal species that were used are, Candida albicans and Trichophyton mentagrophytes. Microbial stock cultures were cultured in nutrient agar for incubation. ${ }^{16}$ The first inhibition zone assay was using $100 \%$ extract of G. latissima Miq. leaves. From the positive results of the first inhibition, the second inhibition zone assay was conducted using the $2 \%$ extract in DMSO (dimethyl sulfoxide) of the leaves. The MIC assay was determined using the broth dilution method. ${ }^{17}$ The MBC was determined by plating out onto each appropriate agar plate. ${ }^{18}$

\section{RESULTS}

\section{Macroscopic characteristics}

Macroscopically, the leaf had a simple composition, it had ovalis shape, margins integer, and the venation patterns of leaves were parallel. It had obtusus apex and base, and thick. The leaves were $15-30 \mathrm{~cm}$ in length and $10-20 \mathrm{~cm}$ in width. The upper surface was laevis, nitidus, and had dark green color. The lower surface had light or pale green color (Figure. 1).

\section{Microscopic characteristics}

The transverse section of G. latissima Miq. leaf showed the presence of upper and lower epidermis that was covered with a single layer of cuticle. The sklerenkim ured red because it react to floroglusin in chloride acid (Figure. 2).

There are diacytis stomata on longitudinal section was analyzed and photomicrographed (Figure. 3).

Powder study: the crude powder of the leaves were pale brown in colour. The diagnostic features of powder were tetragonal type of crystals of calcium oxalate (Figure. 4).

\section{Phytochemical analysis}

The average of extracts rendemen from the result of multilevel maceration extraction from G. latissima Miq. leaves powder with different solvent are shown in Table 1.

The results of phytochemical tests are in the Table 2. Alkaloids were present in the $n$-hexane extracts and ethyl acetate extracts.

\section{Antimicrobial activity}

The results of the antimicrobial activities of n-hexane, ethyl acetate and methanolic extracts of G. latissima Miq. leaves are tabulated in Table 3.

All of the extracts showed the inhibition against the selected pathogens. The zone of inhibition of various extracts of G. latissima Miq. was compared with available standard antibiotic disc. The $2 \%$ ethyl acetate extract and the $2 \%$ methanol extract showed that it only active against B. subtilis with the diameter of ethyl acetat extract inhibition zone was $7.68 \pm 0.076 \mathrm{~mm}$ and the diameter of methanolic extract inhibition zone was $9.9 \pm 0.786 \mathrm{~mm}$ (Table 4 ).

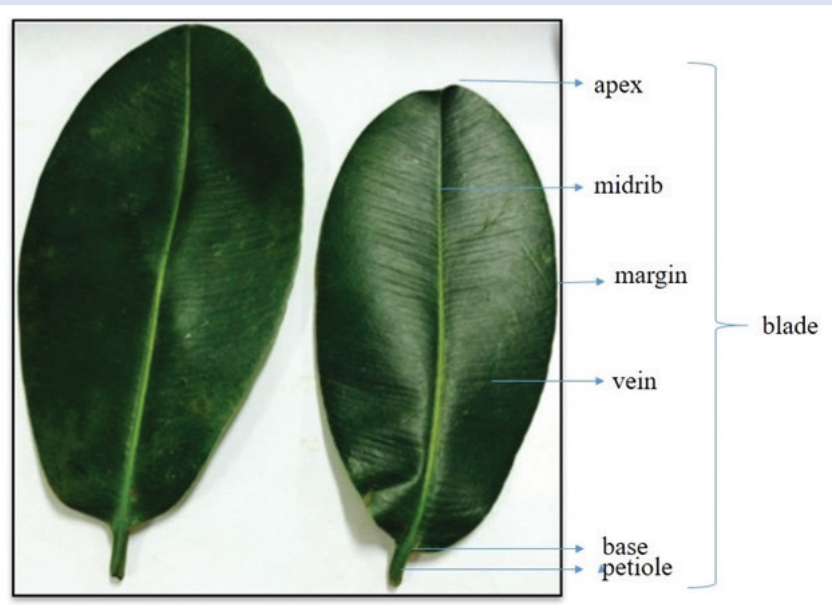

Figure 1: Macroscopic characteristics of G. latissima Miq. Leaves

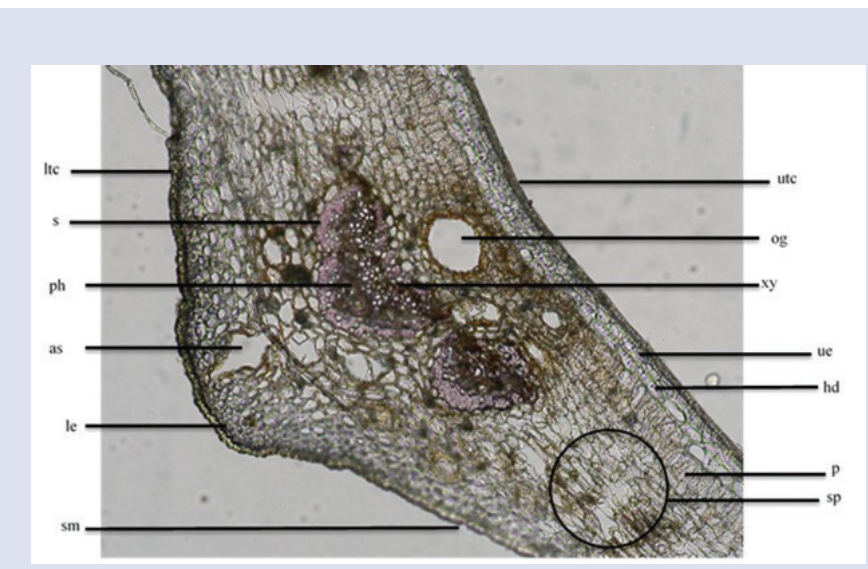

Figure 2: The Photomicrographs of a microscopic characteristic of a transverse section of $\mathrm{G}$. latissima Miq. Were: as-air spaces, hd-hypodermis, le-lower epidermis, Itc-lower thick cuticle, og-oil gland, p-palisade, ph-phloem, s-sklerenkim (tured red because it react to floroglusin in chloride acid), sm-stomata, sp-spongy parenchyma, ue-upper epidermis, utc-upper thick cuticle, xy-xylem

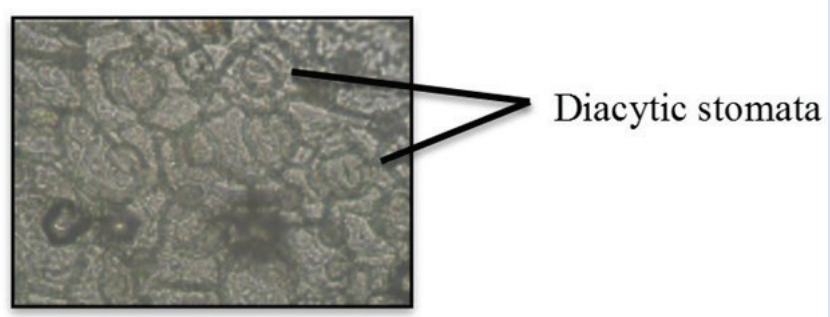

Figure 3: Photomicrographs of a microscopic characteristic of longitudinal section G. latissima Miq. leaf 


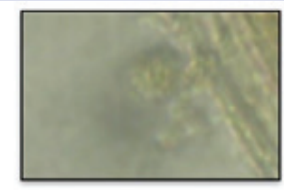

Tetragonal crystals

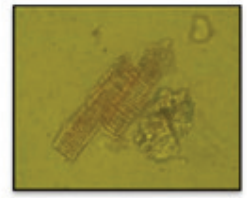

Thickening of the spiral-shaped vessel

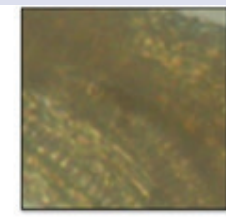

Layer of sclereid from epidermis

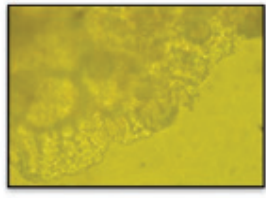

Diacytic stomata

Figure 4: Photomicrographs of a microscopic characteristic of powder of G. latissima Miq. leaf

Table 1: The average of extracts rendemen from the result of multilevel maceration extraction from $\mathrm{G}$. latissima Miq. leaves

\begin{tabular}{ccc}
\hline Solvents & Rendemen (\%) & Average (\%) \\
\hline n-Hexane & 2.918 & $2.7753 \pm 0.2266$ \\
& 2.894 & \\
& 2.514 & \\
Ethyl acetate & 2.938 & $3.3800 \pm 0.3930$ \\
& 3.690 & \\
& 3.512 & \\
Methanol & 24.744 & \\
& 16.094 & \\
& 16.076 &
\end{tabular}

Table 2: Phytochemical screening of G. Iatissima Miq. leaves

\begin{tabular}{ccccc}
\hline Tests & Reagents used & $\begin{array}{c}\mathrm{n} \text {-hexane } \\
\text { extractives }\end{array}$ & $\begin{array}{c}\text { Ethyl acetate } \\
\text { extractives }\end{array}$ & $\begin{array}{c}\text { Methanolic } \\
\text { extractives }\end{array}$ \\
\hline Tannins & Acidic FeCl & - & + & + \\
& Gelatin & - & + & + \\
Saponins & Frothing test & - & - & + \\
Flavonoides & $\mathrm{HCl}+\mathrm{Mg}$ & - & - & - \\
Anthraquinones & turnings & - & - & - \\
Terpenoids & Borntragers's & - & - & - \\
Alkaloids & $\mathrm{H}_{2} \mathrm{SO}_{4}$ & + & + & - \\
& Dragendorff's & - & + & - \\
& Mayer's & + & + & - \\
& Bouchardat's & & & \\
\hline
\end{tabular}

Phytochemical screening : +: intensity reaction, -: non detected

The activity of ethyl acetate extract exhibited against $B$. subtilis (MIC 5,000 ppm, MBC 10,000 ppm) (Table 5). The results of the antibacterial activity showed that the activity of methanol extract exhibited against B. subtilis (MIC 10,000 ppm, MBC 20,000 ppm) (Table 6).

\section{DISCUSSION}

In the present investigation, the detailed pharmacognostic account of G. latissima Miq. leaf will be helpful for botanical identification of the drug. ${ }^{19}$

Table 3: Antibacterial activities of $100 \%$ extracts of G. latissima Miq. leaves

\begin{tabular}{cccc}
\hline \multirow{2}{*}{ Organisms } & \multicolumn{3}{c}{ Zone of inhibition $(\mathrm{mm})$} \\
\cline { 2 - 4 } & $\mathrm{n}$-Hexane & Ethyl acetate & Methanol \\
\hline B. subtilis & - & ++ & ++ \\
C. albicans & - & - & - \\
S. aureus & - & + & + \\
E. coli & - & - & - \\
P. aeruginosa & - & - & + \\
T. mentagrophytes & - & - & - \\
\hline
\end{tabular}

Noted: -: no inhibition zone; +: diameter of inhibition zone $<10 \mathrm{~mm}$; ++: diameter of inhibition zone $\geq 10 \mathrm{~mm}$.

Table 4: Antibacterial activities from $2 \%$ G. Iatissima Miq. leaves extracts in DMSO used agar diffusion method

\begin{tabular}{cccc}
\hline \multirow{2}{*}{ Bacteria } & \multicolumn{3}{c}{ Diameter of inhibition zone $(\mathrm{mm})$} \\
\cline { 2 - 4 } & Ethyl acetate & Metahanol & Antibiotic standard \\
\hline B. subtilis & $7.68 \pm 0.076$ & $9.9 \pm 0.786$ & $21.08 \pm 1.928$ \\
S. aureus & 0 & 0 & $23.70 \pm 1.928$ \\
P. aeuginosa & 0 & 0 & $21.88 \pm 0.511$ \\
\hline
\end{tabular}

The average of results with triplo \pm SD; Antibiotic standard: Erythromycin $15 \mu \mathrm{g}$ for B. subtilis, Gentamycin $10 \mu \mathrm{g}$ for S. aureus, Ciprofloxacin $5 \mu \mathrm{g}$ for P. aeruginosa.

Maceration method was used because it is suitable for first extraction and for extraction in large number. The solvents that were used in this research were non-flammable, not explosive, and non-toxic. The polarity of it were also increase, so the secondary metabolite can dissolved in the three solvents. ${ }^{20}$

Phytochemical analysis: The plant, which utilize a physiological effect, are a biosynthetic laboratory for a multitude of compounds. The compounds that are responsible for imparting therapeutic effects are the secondary metabolites. The preliminary phytochemical analysis will give an idea about the chemical nature of the drug. ${ }^{21}$ The information obtained will be useful in the further structural characterization of the nature of constituents present in this plant. It will be helpful to extract out particular constituents by a particular solvent. ${ }^{22}$

Saponins are a special class of glycoside which have soapy characteristics. Tannins have been reported to prevent the development of microorganisms by precipitating microbial protein and making nutritional proteins unavailable for them. The presence of tannins suggests the ability of this plant to play a major role for the treatment of some disease. ${ }^{19}$

The leaves have to be avoided from direct sunlight to minimize chemical reactions that can occur as a result of ultraviolet rays. It also has to be dried in the oven to prevent microbial fermentation and degradation of metabolites. Dried material is stored in a sealed container in a cool, dry place. Avoid too much time storage, as it can decipher some of the compounds. Milling is done to increase the yield of the extract, the surface area of the sample and solvent penetration into cells. ${ }^{23}$

Medicinal plants that contain thousands of substances are a precursor for the synthesis of useful drugs and are safe to human health. ${ }^{15}$ The concern growing population about health problems has recently led to the development of natural antimicrobials to control the microbial disease. The antimicrobial activity found in the plant extracts have been attributed to some of the secondary metabolites. ${ }^{15}$

The antibacterial activity of plant extracts was not only due to one main active chemical but also due to combined action of other compounds. ${ }^{16}$ 


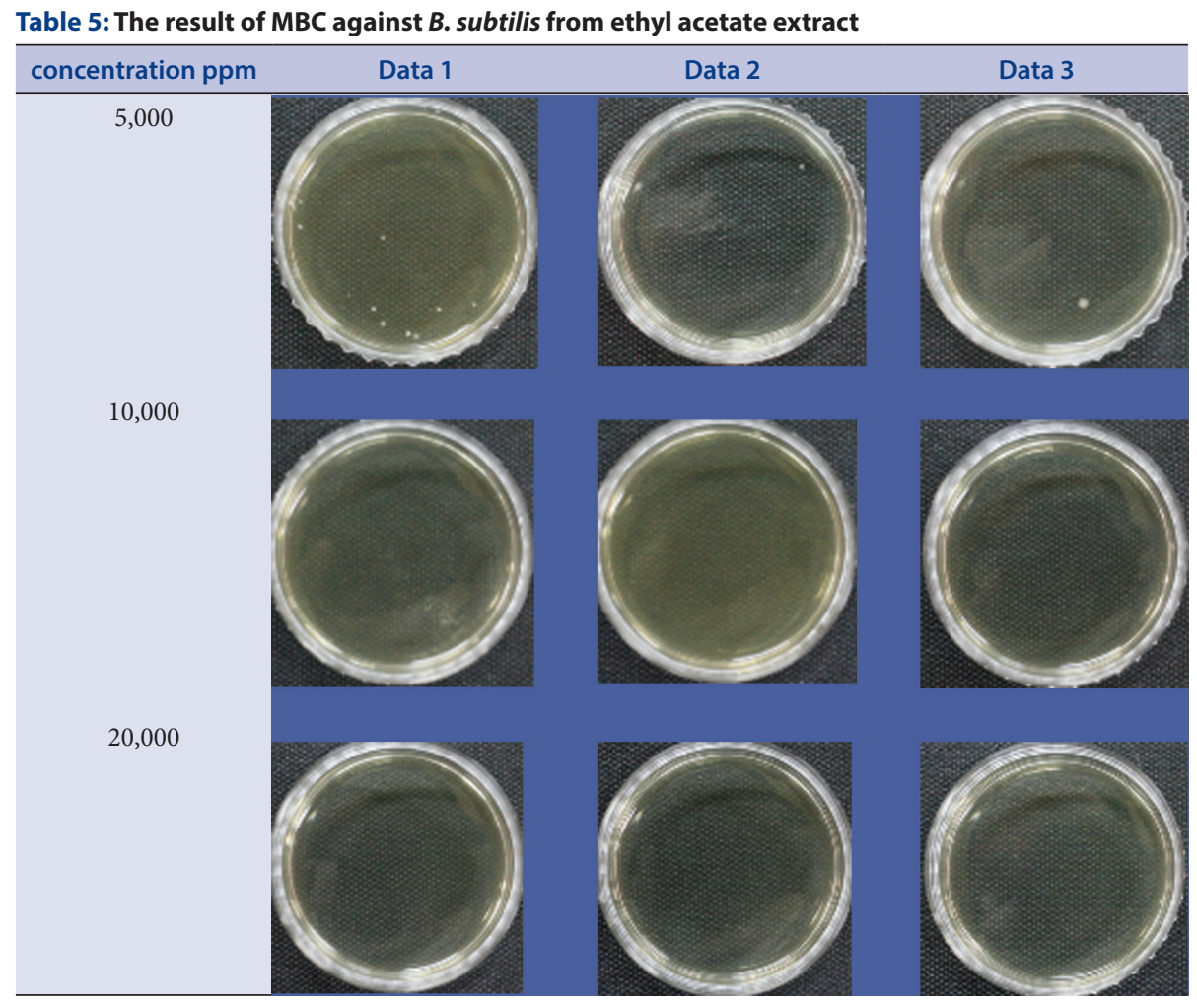

Table 6: The result of MBC against B. subtilis from methanol extract

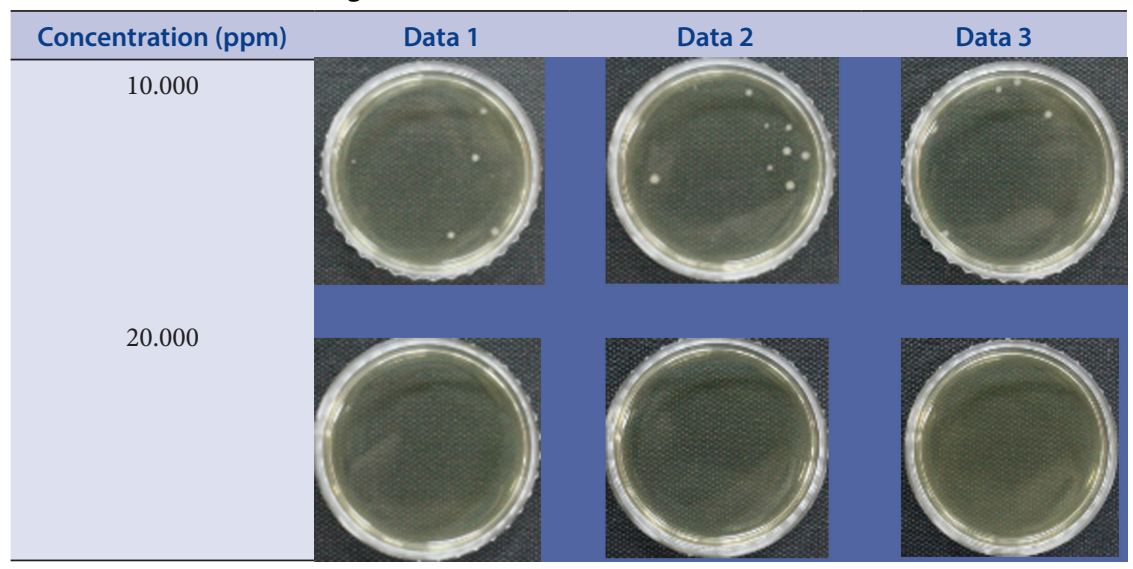

The examples of other compounds are Phenolic acids, alkaloids, flavonoids, terpenes, terpenoids and naphthoquinone. ${ }^{16}$ It is clear that the chemical structure of the antimicrobial agents found in higher plants belong to most commonly encountered classes of higher plant secondary metabolites. ${ }^{16}$

Maceration method is suitable for both initial and bulk extraction. The main disadvantage of maceration is that the process can be quite time-consuming, and also consume large volumes of solvents and can lead to potential loss of metabolites. Some compounds may not be extracted efficiently if they are poorly soluble at room temperature. On the other hand, maceration is less likely to lead to the degradation of thermolabile metabolites. ${ }^{23}$ The physicochemical properties of some common solvents used in natural products extraction: polarity index of $\mathrm{n}$-hexane 0.0 , polarity index of ethyl acetate 4.4 , polarity index of methanol 5.1. The initial choice of the most appropriate solvent is based on its selectivity for the substances to be extracted. A selective extraction can also be performed sequentially with solvents of increasing polarity. ${ }^{23}$ It has done extensive research on the extracts of different types of solvents affect antimicrobial activity inhibition zone. ${ }^{24}$ Methods to detect antimicrobial activity can be classified into three groups: diffusion, dilution, and bioautography. The advantage of the diffusion method is high suitability for pure screening substances.

Microbial used in this study is a gram-positive bacteria (B. subtilis and $S$. aureus), gram-negative bacteria (E. coli and $P$. aeruginosa) and fungi (C. albicans and T. mentagrophytes). ${ }^{25}$

\section{CONCLUSION}

The results of the present study revealed most valuable information and also support the sustainable use of Garcinia latissima Miq. leaves in traditional system of medicine. Moreover, a continuous and progressing research is to be conducted to prove the biological ingredients and test 
the safety, efficiency and to determine the types of compounds responsible for the antimicrobial effect of Garcinia latissima Miq. ${ }^{15}$

Garcinia latissima Miq. showed a good effects in vitro antibacterial. The result presented here may explain the traditional use of this plant. ${ }^{16}$

\section{ACKNOWLEDGEMENT}

The authors thank Center for Plant Conservation Botanic Gardens, Indonesian Institute of Sciences for providing plant material and the confirmation of plant authenticity. We would like to thanks Ministry of Research, Technology and Higher Education of the Republic of Indonesia that provide doctoral dissertation grant in 2017.

\section{CONFLICT OF INTEREST}

None

\section{ABBREVIATION USED}

MIC: The minimum inhibitory concentration; MBC: The minimum bactericidal concentration; ATCC: The American Type Culture Collection; DMSO: dimethyl sulfoxide; SD: standard deviation.

\section{REFERENCES}

1. Stevens PF. The Families and Genera of Fascular Plants. In: Flowering Plants. Vol 9.; 2007:48-66

2. Ilyas M, Kamil M, Parveen M, Khan MS. Isoflavones from Garcinia nervosa. Phytochemistry. 1994;34(3):807-09. https://doi.org/10.1016/S0031-9422(00)89823-4.

3. Verheij E, Coronel RE. Sumber Daya Nabati Asia Tenggara 2, Buah-Buahan Yang Dapat Dimakan. Jakarta: Gramedia; 1997.

4. Swathi P, Jagadeesh T, Madhu M, Vijay C. Protective Responce of Methnolic Extract of Garcinia Indica Fruits on $\mathrm{CCl} 4$ Induced Liver Damage. Pharmacogn J. 2010;2(17):47-52. https://doi.org/10.1016/S0975-3575(10)80009-4.

5. Burkill HM. The Useful Plants of West Tropical Africa, Vol 2. Royal Botanic Gardens, Kew (K); 1985

6. Verheij EWM, Coronel RE. Sumber Daya Nabati Asia Tenggara 2, Buah- Buahan Yang Dapat Dimakan . Jakarta: Gramedia, 216-220. Jakarta: Gramedia; 1997.

7. Xi-Wen L, Jie L, Robson NKB, Stevens PF. Clusiaceae (Guttiferae). Flora of China. 2009;13:1-47.

8. Rao KS. Antibacterial Activity of Some Medicinal Plants of Papua New Guinea. Int J Pharmacogn. 1996;34(3):223-5. https://doi.org/10.1076/phbi.34.3.223.13203.

9. Ito C, Miyamoto Y, Nakayama M, Kawai Y, Rao KS, Furukawa H. A Novel Depsidone and Some New Xanthones From Garcinia Species. Chem Pharm Bull. 1997;45(9):1403-13. https://doi.org/10.1248/cpb.45.1403.

10. Ito $\mathrm{C}$, Itoigawa $\mathrm{M}$, Furukawa $\mathrm{H}$, et al. Xanthones as inhibitors of Epstein-
Barr virus activation. Cancer Lett. 1998;132(1):113-7. https://doi.org/10.1016/ S0304-3835(98)00173-6

11. Conservation R of III of SC for P. An Alphabetical List of Plant Species Cultivated in The Bogor Botanic Gardens.; 2010.

12. Nagar JC, Chauhan LS. Evaluation of Antihyperglycemic and Antihyperlipidemic Activity of Leaf Extracts of Breynia vitis-idaea in Alloxan Induced Diabetic Rats. Pharmacogn J. 2016;8(3):259-263. https://doi.org/10.5530/pj.2016.3.15.

13. Kaneria M, Chanda S. Phytochemical and Pharmacognostic Evaluation of Leaves of Psidium guajava L. (Myrtaceae). Pharmacogn J. 2011;3(23):41-5. https://doi.org/10.5530/pj.2011.23.6.

14. Rissyelly, Lusiyanti SJ, Katrin, Puspitasari N, Gita P, Widyaswari M. ACE Inhibitory Activity, Total Phenolic and Flavonoid Content of Pereskia saccharose Griseb. Leaves Extract. Pharmacogn J. 2017;9(1):285-7.

15. Johnson M, Kalaiarasi V, Sivaraman A, Janakiraman N, Babu A, Narayani M. Phytochemical and Antibacterial Studies on Aristolochia tagala Cham. World J Pharm Res. 2014;3(2):2172-8.

16. Kochuthressia KP, Britto SJ, Jaseentha, Raphael R. In vitro Antimicrobial Evaluation of Kaempferia galanga L. Rhizome Extract. Am J Biotechnol Mol Sci. 2012;2(1):1-5. https://doi.org/10.5251/ajbms.2012.2.1.1.5.

17. Analía TC, Beatriz NM, Inés IM, Paola CM, María GA, Iris Z. Antibacterial Activity of Tinctures from Tree leaves belonging to the Bignoniaceae family and their Synergistic Effect with Antibiotics. Pharmacogn J. 2015;7(6):400-5. https://doi. org/10.5530/pj.2015.6.15.

18. Jeong M-R, Kim H-Y, Cha J-D. Antimicrobial Activity of Methanol Extract from Ficus carica Leaves Against Oral Bacteria. J Bacteriol Virol. 2009;39(2):97-102. https://doi.org/10.4167/jbv.2009.39.2.97.

19. Najafi S, Deokule SS. Pharmacognostic Study of Tylophora dalzellii Hook . f . J Med Plants Res. 2010;4(5):403-6.

20. Seidel V. Initial and Bulk Extraction. In: Sarker SD, Latif Z, Gray Al, eds. Natural Product Isolation. 2nd ed. New Jersey: Humana Press; 2006:27-46. https://doi. org/10.1385/1-59259-955-9:27.

21. Prasanth DSNBK, Rao AS, Yejella RP. Pharmacognostic and Preliminary Phytochemical Investigation of Leaves of Aralia Racemosa L. Pharmacogn $\mathrm{J}$. 2015;8(3):250-4.

22. Menpara D, Desai D, Chanda S. Pharmacognostic, Phytochemical, Physicochemical and Fluorescence Analysis of Terminalia Bellerica Leaf and Stem. World J Pharm Sci. 2014;2(4):390-6.

23. Sarker SD, Latif Z, Gray Al. Natural Products Isolation Second Edition. 2nd ed. New Jersey: Humana Press; 2006. https://doi.org/10.1385/1-59259-955-9:1.

24. Yeo YL, Chia YY, Lee CH, Sow HS, Yap WS. Effectiveness of Maceration Periods with Different Extraction Solvents on In-vitro Antimicrobial Activity from Fruit of Momordica charantia L. J Appl Pharm Sci. 2014;4(10):16-23. doi:10.7324/ JAPS.2014.40104. https://doi.org/10.7324/JAPS.2014.40104.

25. Carroll, Butel, Morse, Mietzner. Jawetz, Melnick \& Adelberg's Medical Microbiology. 27th ed. New York: Mc Graw Hill Education; 2016.
GRAPHICAL ABSTRACT
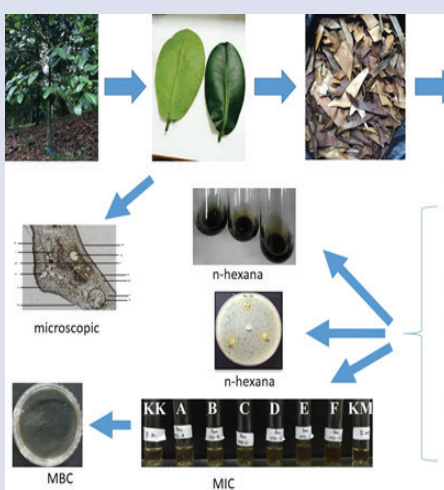

MIC

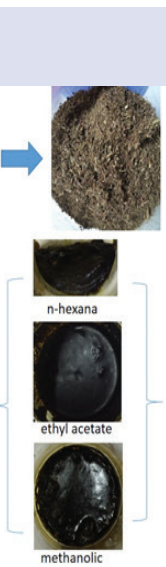

\section{SUMMARY}

- The phytochemical screening of different extract of G. latissima Miq leaves revealed the presence of tannins, saponins, and alkaloids and the results were tabulated.

- The ethyl acetate extracts from its leaves showed antimicrobial activity especially for Bacillus subtilis, a positive bacteria (MIC =5,000 ppm).

- The methanol of G. latissima Miq leaves has activity against Bacillus subtilis (MIC $=10,000$ ppm).

- $\quad$ The hexane extract did not show any activity against the selected microba.

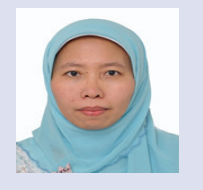

Neneng Siti Silfi Ambarwati, a Doctoral Student at Department of Pharmaceutical Sciences, Faculty of Pharmacy, Universitas Indonesia, Depok, West Java, Indonesia, and also as a lecturer at Department of Health and Beauty, Faculty of Engineering, Jakarta State University, East Jakarta, Indonesia. The doctoral research focused on the isolation, identification, semi-synthetic of the active compound aas antibacterial. 


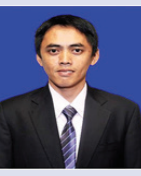

Islamudin Ahmad, a Doctoral Student at Department of Pharmaceutical Sciences, Faculty of Pharmacy, Universitas Indonesia (UI), Depok, West Java, Indonesia. He also as a lecturer at Faculty of Pharmacy, Mulawarman University, Samarinda, East Kalimantan, Indonesia. The doctoral research focused on the study of screening activity and angiotensin converting enzyme (ACE) inhibitory active compound from the natural product for drugs discovery as antihypertension .

Prof. Dr. Berna Elya, Professor and Head of Phytochemistry and Pharmacognosy, Faculty of Pharmacy, Universitas Indonesia (UI) Depok, West Java, Indonesia. She is expert in the area of Pharmacognosy and Phytochemistry, working in drug discovery of herbal plants, extraction technology, structure elucidation, and degenarative disease such as diabetes mellitus, antyhypertension, and cholesterol.

Prof. Dr. Amarila Malik, Professor and Head of Microbiology and Biotechnology Laboratory, Faculty of Pharmacy, Universitas Indonesia (UI) Depok, West Java, Indonesia. Her major research interests are microbiology, biotechnology, molecular biology, genetic engineering, and pharmacogenomic/pharmacogenetic, as reflected in her publications.

Prof. Dr. Muhammad Hanafi, Professor and Head of natural products, foods, and pharmaceuticals of Research Centre for Chemistry Indonesian Institute of Sciences, Serpong, Banten, Indonesia. He is expert in active compounds isolation and identification, and structure activity relationship.

Cite this article: Ambarwati NSS, Ahmad I, Elya B, Malik A, Hanafi M. Pharmacognostic and Antimicrobial Studies of Garcinia latissima Miq. Leaves (Clusiaceae). Pharmacog J. 2017;9(4):493-8. 